\title{
Relative nitrogen efficiency, a new indicator to assess crop livestock farming systems
}

\author{
Olivier Godinot • Philippe Leterme • Françoise Vertès • \\ Philippe Faverdin $\cdot$ Matthieu Carof
}

Accepted: 9 January 2015 /Published online: 4 March 2015

(C) INRA and Springer-Verlag France 2015

\begin{abstract}
Improving nitrogen (N) efficiency is a priority for increasing food production while reducing its environmental impacts. $\mathrm{N}$ efficiency indicators are needed to achieve this goal, but current indicators have some limitations. In particular, current $\mathrm{N}$ efficiency indicators are not appropriate tools to compare farming systems with different types of production because animal $\mathrm{N}$ efficiency is, by nature, lower than crop $\mathrm{N}$ efficiency. A novel $\mathrm{N}$ efficiency indicator called "relative $\mathrm{N}$ efficiency" was developed to address this issue. It was calculated as the ratio of the actual $\mathrm{N}$ efficiency of the farming system to the weighted mean of the potential efficiency of each type of product output provided in literature reviews. Relative $\mathrm{N}$ efficiency was calculated for 557 farms of various types from France and Italy. The relative $\mathrm{N}$ efficiency indicator was validated by comparison with a statistical approach based on multiple linear regression. Statistical analysis showed that relative $\mathrm{N}$ efficiency was independent of production type and could therefore be used for unbiased comparison of different farming systems. Relative $\mathrm{N}$ efficiency was particularly interesting when comparing mixed farming systems with different proportions of animal and crop production.
\end{abstract}

O. Godinot $\cdot$ P. Leterme $\cdot$ F. Vertès

Agrocampus Ouest, UMR1069 Sol Agro et hydrosystème

Spatialisation, F-35000 Rennes, France

O. Godinot $\cdot$ P. Leterme $\cdot$ F. Vertès $\cdot$ M. Carof

INRA, UMR1069 Sol Agro et hydrosystème Spatialisation,

F-35000 Rennes, France

P. Faverdin

INRA, UMR1348 PEGASE, F-35590 Saint-Gilles, France

P. Faverdin

Agrocampus Ouest, UMR1348 PEGASE,

F-35590 Saint-Gilles, France

M. $\operatorname{Carof}(\bowtie)$

Agrocampus Ouest, UMR1069 Sol Agro et hydrosystème

Spatialisation, 65 rue de Saint-Brieuc, 35042 Rennes Cedex, France

e-mail: matthieu.carof@agrocampus-ouest.fr
Keywords Relative nitrogen efficiency $\cdot$ Potential nitrogen efficiency $\cdot$ Farming system comparison $\cdot$ Indicator $\cdot$ Diagnosis tool

\section{Introduction}

Improving nitrogen $(\mathrm{N})$ efficiency is a major way to increase agricultural productivity while reducing environmental impacts of agriculture (Spiertz 2010; Sutton et al. 2011). N use efficiency can be defined as the ratio of $\mathrm{N}$ outputs to $\mathrm{N}$ inputs at the animal (Van der Hoek 1998), crop (Oenema et al. 2009) or farm scale (Aarts et al. 2000). It is the most widely used indicator to assess the potential impact of farming practices on $\mathrm{N}$ efficiency and to design more efficient farming systems (Simon et al. 2000; Powell et al. 2010; Oenema et al. 2012). N eco-efficiency indicators at the farm scale (Halberg et al. 2005; Nevens et al. 2006) use the same data to express production efficiency relatively to $\mathrm{N}$ losses instead of $\mathrm{N}$ inputs. These indicators present several limitations, such as the artificial improvement of efficiency due to purchased feed or the non-consideration of soil $\mathrm{N}$ changes (Schröder et al. 2003). Recently, Godinot et al. (2014) proposed ways to correct them. One important limitation not addressed in previous work is that $\mathrm{N}$ efficiency indicators only allow comparison of farming systems when they have a similar production type and intensity (Godinot et al. 2014; Lebacq et al. 2012; Nevens et al. 2006).

This limitation exists because crop production and animal production do not have the same $\mathrm{N}$ efficiencies (Goulding et al. 2008; Ramírez and Reheul 2009). Arable crops (thereafter named crops) and grasslands are primary producers that use inorganic nutrients to produce biomass through photosynthesis, while nearly all farm animals are primary consumers that derive most nutrients and energy from plants. This difference in trophic level induces a systematic difference in nutrient use efficiency. The $\mathrm{N}$ transferred from inorganic sources to animal products is based on plant $\mathrm{N}$ efficiency, but also includes feed production losses at harvest and processing, feed losses during conservation and consumption, and assimilation 
losses resulting in $\mathrm{N}$ excretion. Therefore, the $\mathrm{N}$ efficiency in livestock systems is biologically lower than in cropping systems (Figure 1). This makes comparisons between farming systems with different proportions of crops and livestock or different types of livestock less meaningful for modifying farm practices to increase $\mathrm{N}$ efficiency.

The aim of this study was to develop an indicator of $\mathrm{N}$ efficiency that allows the relative efficiency of farming systems that produce outputs of different trophic levels to be compared. This would help farmers and advisors to compare the efficiency of farming systems with different products, and could allow policy makers to set efficiency objectives for all types of farming systems. The Materials and Methods section details the methodology used for calculating this new indicator. A literature review provides references for potential efficiency of each output. The indicator is then calculated for a sample of 557 farms with various types of crop and animal production. A comparison of these results with a multiple linear regression allows validating the selected potential efficiency values, and thus the developed indicator. The interests of relative $\mathrm{N}$ efficiency are presented and discussed in the third section, with a focus on the significance and limits of this novel indicator. The fourth section provides a summary and concluding remarks.

\section{Materials and methods}

\subsection{Presentation of the data}

\subsubsection{Farm sample}

Data were obtained from a previous work by Simon et al. (2000). The sample comprised 557 farms surveyed from 1989 to 1994 to calculate farm gate $\mathrm{N}$ balances $(\mathrm{N}$ inputs minus $\mathrm{N}$ outputs at the farm scale) and $\mathrm{N}$ use efficiencies. It was

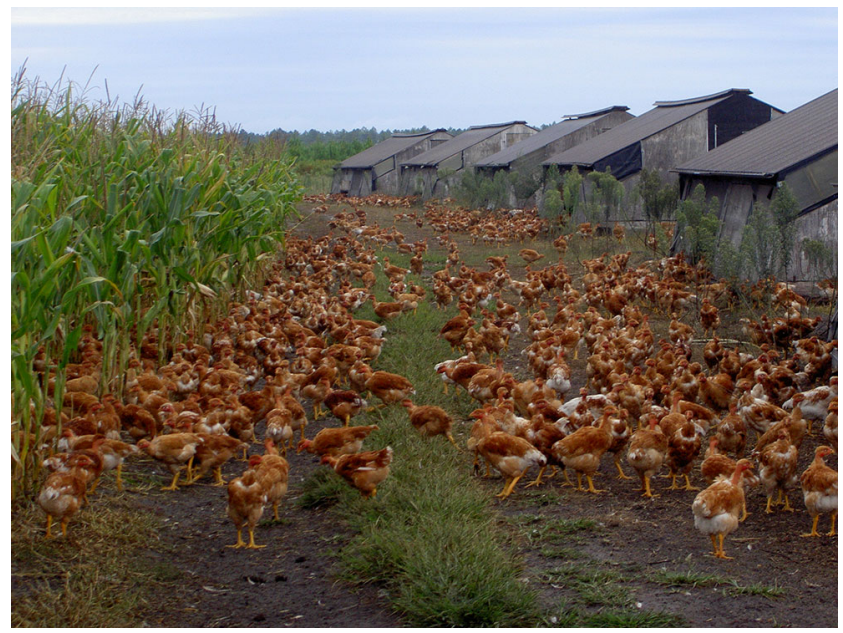

Fig. 1 Chickens in a corn field. Animal products have, by nature, a lower $\mathrm{N}$ efficiency than crops, which makes $\mathrm{N}$ efficiency comparisons between different farming systems problematic (Credit D. Poulain) constructed to represent a large diversity of production types and included farms that produced crops, milk, beef cattle, poultry, eggs, and/or pigs. Most farms had conventional production, but 52 were organic, and 29 were defined as "autonomous" in which farmers replaced inorganic fertilizers with legume crops. They also represented a wide range of soils and climates, with 379 farms from western France (mostly cambisols, oceanic climate), 111 farms from northern Italy (mostly gleyic luvisols, subtropical wet climate), 36 farms from northern France (mostly haplic luvisols, oceanic climate), and 31 farms from eastern France (mostly rendzic leptosols, semi-continental climate). Such a large and diversified dataset was valuable for the methodological developments proposed in this article. However, data were collected over 20 years ago and cannot be considered representative of current farming practices.

\subsubsection{Estimation of $N$ inputs and outputs and classification of farming systems}

System N efficiency (Godinot et al. 2014) is an N efficiency indicator at the farming system scale. It is based on $\mathrm{N}$ use efficiency, but considers net inputs and outputs, $\mathrm{N}$ used for the production and transport of net inputs, as well as soil $\mathrm{N}$ variations. These modifications make System $\mathrm{N}$ efficiency a more relevant indicator than $\mathrm{N}$ use efficiency for farming systems comparison. We, therefore, decided to base the development of our relative efficiency indicator on System $\mathrm{N}$ efficiency.

Most $\mathrm{N}$ flows needed to calculate system $\mathrm{N}$ efficiency were available in the dataset. $\mathrm{N}$ outputs included manure, crops, and animal products. $\mathrm{N}$ inputs consisted of feed and litter, manure and inorganic fertilizers, purchased animals, and biological $\mathrm{N}$ fixation. However, as they admit, Simon et al. (2000) likely underestimated biological $\mathrm{N}$ fixation of grasslands in organic and autonomous farms by assuming a constant $10 \%$ of above-ground dry matter as clover in grasslands of all farms. Andrews et al. (2007) considered that in mixed perennial ryegrass and white clover grasslands that receive no mineral fertilizer, white clover was likely to stabilize at around $20 \%$ of above-ground dry matter. Since organic and autonomous farms relied heavily on grass-clover mixtures in their grasslands, we recalculated biological $\mathrm{N}$ fixation for these farms assuming $20 \%$ of above-ground dry matter as clover in grasslands. Atmospheric $\mathrm{N}$ deposition was estimated using national means for 1990 from the EMEP/MSC-W model (EMEP 2014). This led to total atmospheric $\mathrm{N}$ deposition of $13 \mathrm{~kg} \mathrm{~N} \mathrm{ha}^{-1}$ for French farms and $17.5 \mathrm{~kg} \mathrm{~N} \mathrm{ha}^{-1}$ for Italian farms. Due to limited data on soil management, soil $\mathrm{N}$ variations were estimated from onfarm crop areas. Soils under annual crops were assumed to lose $70 \mathrm{~kg} \mathrm{~N} \mathrm{ha}^{-1}$ year $^{-1}$, while grasslands were assumed to store $43 \mathrm{~kg} \mathrm{~N} \mathrm{ha}^{-1}$ year $^{-1}$ (values derived from Vleeshouwers and Verhagen 2002 with a C:N ratio of 12). Seed N input and indirect $\mathrm{N}$ losses from seed production and transport were calculated 
according to Godinot et al. (2014). We used constants to represent small $\mathrm{N}$ inputs such as non-symbiotic $\mathrm{N}$ fixation by freeliving soil microorganisms, fuel combustion, and indirect $\mathrm{N}$ losses for fuel production and transport (Godinot et al. 2014). We calculated the indirect losses due to fertilizer production based on the percentage of each inorganic fertilizer in the total mass of inorganic fertilizers used in France from 1989 to 1994 (UNIFA 2014). Similarly, feed composition was estimated from the percentage of each feedstuff in the total mass of main feedstuffs used in France in 1993-1994 (Castel and Pous 1998) to approximate its indirect losses. Only a few dairy farms had net animal inputs. For these farms, indirect losses from animal production and transport were calculated using life cycle assessment references. We assumed that no change in stock occurred from year to year except for soil $\mathrm{N}$.

Table 1 presents direct and indirect $\mathrm{N}$ inputs and outputs for the 557 farms.

We classified farming systems into nine categories according to the composition of their net $\mathrm{N}$ outputs (Table 1). For instance, the "crops" category was made of farming systems with only net crop outputs (regardless of the different types of crops), while the "milk" category gathered farming systems

Table 1 Mean net annual $\mathrm{N}$ inputs and outputs from the nine farming system categories $\left(\mathrm{kg} \mathrm{N} \mathrm{ha}^{-1}\right.$ agricultural area). Standard deviations are in parentheses

\begin{tabular}{|c|c|c|c|c|c|c|c|c|c|c|c|c|c|c|c|c|c|c|}
\hline \multirow[b]{2}{*}{ Number of farms } & \multicolumn{2}{|l|}{$\begin{array}{l}\text { Beef } \\
\text { cattle }\end{array}$} & \multicolumn{2}{|c|}{$\begin{array}{l}\text { Beef cattle } \\
\text { and } \\
\text { crops }\end{array}$} & \multicolumn{2}{|c|}{$\begin{array}{l}\text { Beef cattle } \\
\text { and pigs }\end{array}$} & \multicolumn{2}{|c|}{ Crops } & \multicolumn{2}{|c|}{$\begin{array}{l}\text { Crops } \\
\text { and milk }\end{array}$} & \multicolumn{2}{|l|}{ Milk } & \multicolumn{2}{|c|}{$\begin{array}{l}\text { Milk } \\
\text { and pigs }\end{array}$} & \multicolumn{2}{|l|}{ Pigs } & \multicolumn{2}{|c|}{ Poultry } \\
\hline & 47 & & 35 & & 13 & & 24 & & 53 & & 299 & & 36 & & 30 & & 20 & \\
\hline Agricultural area & 43 & $(25)$ & 79 & $(38)$ & 39 & (23) & 121 & (157) & 68 & (37) & 44 & (25) & 39 & (16) & 38 & (26) & 45 & (18) \\
\hline \multicolumn{19}{|l|}{ Net inputs } \\
\hline Atm. deposition & 14 & (2) & 14 & (2) & 13 & $(0)$ & 13 & $(0)$ & 14 & (2) & 14 & (2) & 13 & $(0)$ & 13 & $(0)$ & 13 & $(0)$ \\
\hline $\mathrm{BNF}$ & 14 & (22) & 26 & (29) & 21 & $(47)$ & 32 & (35) & 23 & (32) & 22 & $(31)$ & 7 & (17) & 4 & (12) & 12 & $(20)$ \\
\hline Cattle & & & & & & & & & 0 & (3) & 0 & (1) & & & & & & \\
\hline Cattle indir. loss & & & & & & & & & 2 & (11) & 0 & (2) & & & & & & \\
\hline Feed & 69 & (107) & & & 321 & (203) & & & & & 98 & $(170)$ & 302 & $(235)$ & 918 & (964) & 292 & (279) \\
\hline Feed indir. loss & 18 & (28) & & & 86 & $(54)$ & & & & & 26 & $(45)$ & 80 & $(62)$ & 244 & (257) & 78 & (74) \\
\hline Fuel $^{\mathrm{a}}$ & 3 & $(0)$ & 3 & $(0)$ & 3 & $(0)$ & 3 & $(0)$ & 3 & $(0)$ & 3 & $(0)$ & 3 & $(0)$ & 3 & $(0)$ & 3 & $(0)$ \\
\hline Fuel indir. loss & 0 & $(0)$ & 0 & $(0)$ & 0 & $(0)$ & 0 & $(0)$ & 0 & $(0)$ & 0 & $(0)$ & 0 & $(0)$ & 0 & $(0)$ & 0 & $(0)$ \\
\hline Inorg. fertilizer & 100 & (84) & 99 & $(53)$ & 70 & $(51)$ & 97 & (74) & 100 & (51) & 114 & (73) & 123 & (53) & 83 & (44) & 103 & $(52)$ \\
\hline $\begin{array}{l}\text { Inorg. fertilizer } \\
\text { indir. loss }\end{array}$ & 2 & (1) & 2 & (1) & 1 & (1) & 2 & (1) & 2 & (1) & 2 & (1) & 2 & (1) & 1 & (1) & 2 & (1) \\
\hline Manure & 15 & $(70)$ & 1 & (4) & -18 & (78) & 25 & (70) & -1 & (4) & 1 & (26) & -17 & $(72)$ & -227 & (394) & -24 & $(63)$ \\
\hline Seeds & 1 & (1) & 2 & (1) & 1 & (1) & 3 & (1) & 1 & (1) & 1 & $(0)$ & 1 & $(0)$ & 2 & $(0)$ & 1 & (1) \\
\hline Seeds indir. loss & 1 & (1) & 1 & $(0)$ & 2 & (1) & 2 & $(0)$ & 1 & $(0)$ & 1 & (1) & 1 & $(0)$ & 2 & $(0)$ & 2 & (1) \\
\hline Soil $\mathrm{N}$ fixation ${ }^{\mathrm{a}}$ & 5 & $(0)$ & 5 & $(0)$ & 5 & $(0)$ & 5 & $(0)$ & 5 & $(0)$ & 5 & $(0)$ & 5 & $(0)$ & 5 & $(0)$ & 5 & $(0)$ \\
\hline Soil $N$ change & -16 & (43) & -31 & (24) & -37 & $(28)$ & -61 & (21) & -22 & (24) & -7 & $(25)$ & -17 & (19) & -66 & (8) & -29 & $(30)$ \\
\hline $\begin{array}{l}\text { Total net inputs } \\
\text { — soil N change }\end{array}$ & 258 & (228) & 184 & $(55)$ & 543 & (249) & 242 & (81) & 172 & $(58)$ & 295 & $(235)$ & 538 & (267) & 1114 & (832) & 515 & (320) \\
\hline
\end{tabular}

\section{Net outputs}

\begin{tabular}{|c|c|c|c|c|c|c|c|c|c|c|c|c|c|c|c|c|c|c|}
\hline Beef cattle & 30 & (31) & 6 & (6) & 9 & (8) & & & 4 & (3) & 7 & (7) & 6 & (2) & & & 7 & (6) \\
\hline Crops & & & 49 & (33) & & & 101 & $(48)$ & 29 & $(25)$ & & & & & & & & \\
\hline Milk & & & & & & & & & 15 & (8) & 43 & (42) & 36 & (13) & & & 20 & $(20)$ \\
\hline Pigs & & & & & 85 & $(51)$ & & & & & & & 76 & $(66)$ & 262 & (256) & & \\
\hline Eggs & & & & & & & & & & & & & & & & & 27 & $(71)$ \\
\hline Poultry & & & & & & & & & & & & & & & & & 83 & (115) \\
\hline Total net outputs & 30 & (31) & 56 & (31) & 95 & (49) & 101 & $(48)$ & 48 & $(25)$ & 50 & (44) & 118 & (74) & 262 & (256) & 138 & (112) \\
\hline
\end{tabular}

Atm. atmospheric, $B N F$ biological $\mathrm{N}$ fixation, indir. loss indirect $\mathrm{N}$ losses due to input production and transport to the farm, Inorg. inorganic

${ }^{\text {a }}$ Constant value 
having net milk outputs as well as net cattle outputs from the dairy herd. The "pig" category included farms producing pigs only and farms producing pigs and crops, as the difference between feed inputs and crop outputs always resulted in positive net feed input and zero net crop output. There was, thus, no "pig and crops" category. In order to avoid categories with
Table 2 Potential efficiencies of main $\mathrm{N}$ flows in farming systems and their sources

\begin{tabular}{|c|c|c|c|}
\hline $\mathrm{N}$ flow & Efficiency name & $\begin{array}{l}\text { Potential } \\
\text { efficiency }\end{array}$ & Source \\
\hline $\begin{array}{l}\text { External input to soil } \\
\text { (biological N } \\
\text { fixation) }\end{array}$ & Input efficiency & $100 \%$ & Eggleston et al. (2006) \\
\hline \multicolumn{4}{|l|}{ Manure to soil } \\
\hline - Cattle grazing & Manure efficiency & $93 \%$ & Aarts et al. (2000) \\
\hline - Cattle grazing & & $85 \%$ & Rotz (2004) \\
\hline - Poultry & & $82 \%$ & Rotz (2004) \\
\hline - Cattle at stable & & $79 \%$ & Rotz (2004) \\
\hline - Pig & & $77 \%$ & Rotz (2004) \\
\hline - Cattle grazing + stable & & $76-84 \%$ & Steinshamn et al. (2004) \\
\hline - Cattle grazing + stable & & $75 \%$ & Powell et al. (2010) \\
\hline \multicolumn{4}{|l|}{ Soil to harvestable crop } \\
\hline - Grassland & Crop efficiency & $91 \%$ & Oenema et al. (2012) \\
\hline - Arable crops, fruits & & $90 \%$ & $\begin{array}{l}\text { Task Force on Reactive } \\
\text { Nitrogen (2011) }\end{array}$ \\
\hline - Grass-clover ley & & $89 \%$ & Steinshamn et al. (2004) \\
\hline - Silage maize & & $88 \%$ & Zavattaro et al. (2012) \\
\hline - Undefined crops & & $80 \%$ & Powell et al. (2010) \\
\hline - Vegetables & & $80 \%$ & $\begin{array}{l}\text { Task Force on Reactive } \\
\text { Nitrogen (2011) }\end{array}$ \\
\hline - Grain maize & & $77 \%$ & Moll et al. (1982) \\
\hline - Wheat (grain only) & & $69 \%$ & Górny et al. (2011) \\
\hline \multicolumn{4}{|l|}{ Harvestable to harvested crop } \\
\hline - Silage maize & Harvest efficiency & $95 \%$ & Rotz et al. (2012) \\
\hline - Cereals & & $93 \%$ & Rotz et al. (2012) \\
\hline - Cereals and forages & & $89 \%$ & Steinshamn et al. (2004) \\
\hline \multicolumn{4}{|l|}{ Harvested crop to feed } \\
\hline - Full diet w/ grazing & Feed production efficiency & $93 \%$ & Steinshamn et al. (2004) \\
\hline - Full diet & & $86 \%$ & Aarts et al. (2000) \\
\hline \multicolumn{4}{|l|}{ Feed to milk } \\
\hline - W/ dry period & Feed-to-milk efficiency & $30 \%$ & Chase (2004) \\
\hline - W/ dry period & & $30 \%$ & Gourley et al. (2012) \\
\hline - W/ dry period, confined & & $30 \%$ & Powell et al. (2010) \\
\hline - W/ dry period, grazing & & $25 \%$ & Powell et al. (2010) \\
\hline Feed to cattle & Feed-to-cattle efficiency & $17 \%$ & $\begin{array}{l}\text { Micol et al. (2003), Biagini and } \\
\text { Lazzaroni (2013) }\end{array}$ \\
\hline Feed to pig & Feed-to-pig efficiency & $41 \%$ & Cederberg and Flysjö (2004) \\
\hline \multirow[t]{2}{*}{ Feed to egg } & Feed-to-egg efficiency & $40 \%$ & Singh et al. (2009) \\
\hline & & $39 \%$ & Rios et al. (2009) \\
\hline Feed to poultry & Feed-to-poultry efficiency & $57 \%$ & Ebling et al. (2013) \\
\hline
\end{tabular}

Values used in this study are indicated in bold letters $w /$ with 
a very small number of farms, we aggregated both specialized poultry farms that only had net poultry and/or egg outputs, and poultry farms combined with other net animal outputs (beef cattle and/or milk) into a wider "poultry" category. Very important $\mathrm{N}$ flows per hectare in all categories including pig production are explained by intensive pig production on small agricultural areas. This was still common in France in the years 1990 but has changed with the implementation of the Nitrate Directive (91/676/EEC).

\subsection{Development of the relative $\mathrm{N}$ efficiency indicator}

\subsubsection{Review of potential $N$ efficiencies}

Calculation of relative $\mathrm{N}$ efficiency is based on the potential efficiency (i.e., the best efficiency that can be attained in optimal conditions) of $\mathrm{N}$ transfers between farm components (soil, crops, feed, animals). A review of existing literature was performed to determine the potential $\mathrm{N}$ efficiency for the main $\mathrm{N}$ flows in farming systems (Table 2, Fig. 2). N flow efficiency was calculated as the ratio of $\mathrm{N}$ outputs to $\mathrm{N}$ inputs. For the purpose of this review, it was assumed that the $\mathrm{N}$ efficiency of each flow was independent.

Biological $\mathrm{N}$ fixation was estimated to generate no direct $\mathrm{N}$ loss in the latest IPCC guidelines (Eggleston et al. 2006). This was also the case for atmospheric $\mathrm{N}$ deposition, which although a serious environmental issue, generates no direct emissions for the farming system receiving it. Therefore, the potential input $\mathrm{N}$ efficiency could be as high as $100 \%$ ( $\mathrm{N}$ flow: external input to soil, Table 2).

Manure $\mathrm{N}$ produced by animals was calculated as the difference between $\mathrm{N}$ in feed intake and $\mathrm{N}$ in animal products. According to Rotz (2004), minimum N losses from excretion to the soil were $21 \%$ for cattle in tied stables, $15 \%$ for grazing animals, $23 \%$ for swine on slatted floors with an enclosed slurry tank and deep injection, and $18 \%$ for poultry raised in cages. For the sake of generality, the lowest value was used for all animal types, leading to a $77 \%$ manure $\mathrm{N}$ efficiency ( $\mathrm{N}$ flow: manure to soil, Table 2). This value is similar to those proposed by other authors for dairy herds (Steinshamn et al. 2004; Powell et al. 2010). Harvest losses, crop residues, and manure are not desired outputs; however, they can improve $\mathrm{N}$ efficiency by replacing external inputs with recycled $\mathrm{N}$ returned to the soil; thus, they were considered to be fully recycled when calculating potential efficiency.

A potential crop efficiency of $90 \%$ ( $\mathrm{N}$ flow: soil to harvestable crop, Table 2) is proposed by the Task Force on Reactive Nitrogen (2011) for arable crops. This value is close to other references for cereals and grasslands (Table 2). As we did not find pertinent references for some of the major crop types (oilseeds,
Fig. 2 Potential $\mathrm{N}$ efficiencies of the main flows in farming systems. Black arrows represent $\mathrm{N}$ flows with their potential efficiencies. Dashed arrows represent the partition between crops used as feed and those sold. Gray shaded boxes are the net N output data needed to calculate potential efficiency at the farming system scale. *Excreted $\mathrm{N}$ efficiency calculated as 1-animal $\mathrm{N}$ efficiency

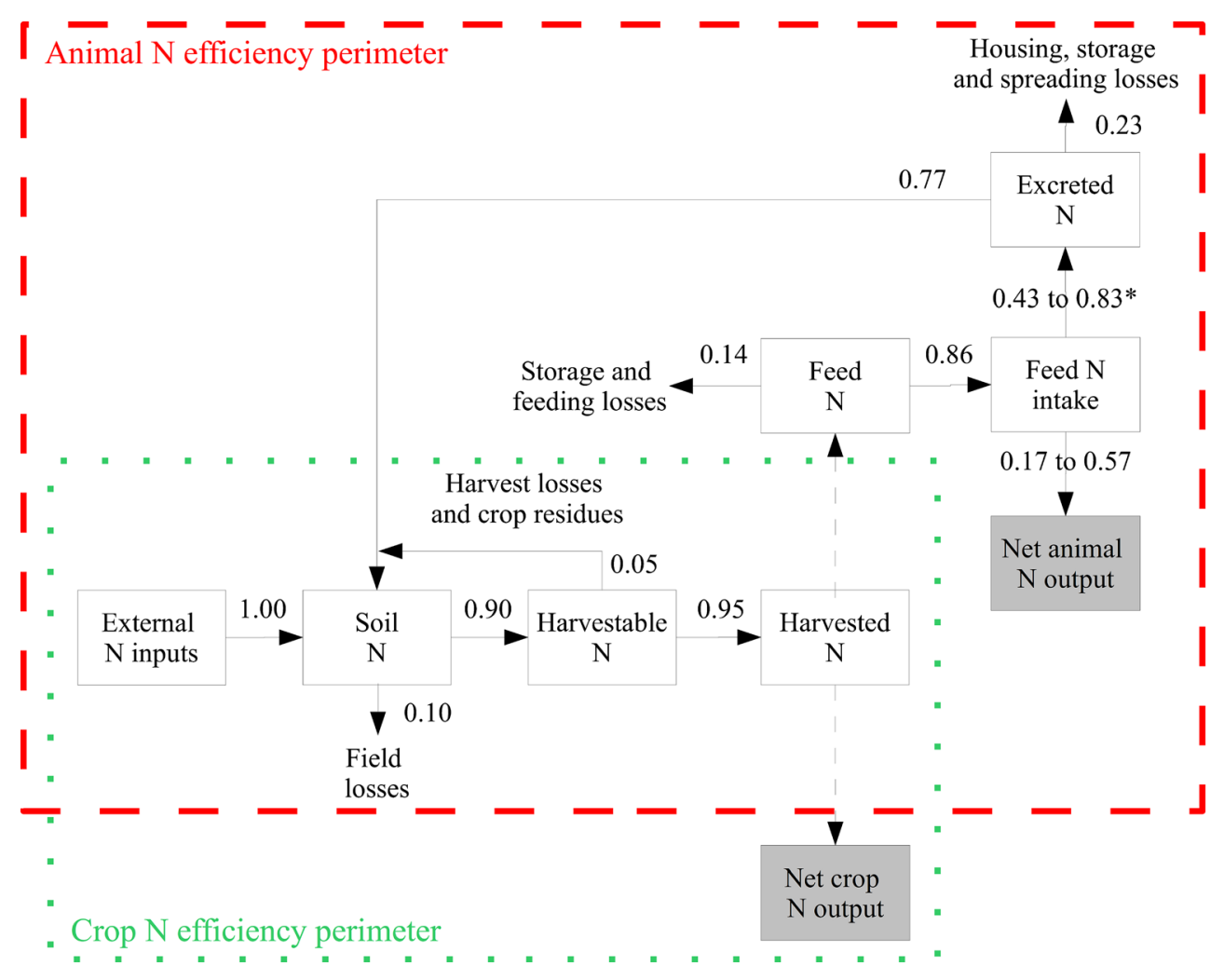


legumes, root crops), we chose to use this value for all crops as a first estimate. Soil $\mathrm{N}$ stock variations were assumed to be zero when calculating potential efficiencies, since we considered that the most efficient use of $\mathrm{N}$ was to produce $\mathrm{N}$ outputs without decreasing soil $\mathrm{N}$ stock.

Rotz et al. (2012) found minimal harvest $\mathrm{N}$ losses of $5 \%$ of total yield, which gave a potential harvest $\mathrm{N}$ efficiency of $95 \%$ ( $\mathrm{N}$ flow: harvestable to harvested crop, Table 2).

Conservation and feeding losses were taken from Aarts et al. (2000), who estimated minimum $\mathrm{N}$ losses of $14 \%$ from harvested crop to feed intake. This led to a potential feed production $\mathrm{N}$ efficiency of $86 \%(\mathrm{~N}$ flow: harvested crop to feed, Table 2). We chose not to use the higher reference based on grazing (Steinshamn et al. 2004), as it could not be attained in some animal farming systems.

The feed-to-milk $\mathrm{N}$ efficiency of dairy cows was calculated from the highest reported feed-to-milk $\mathrm{N}$ efficiency for a dairy herd (35.8\%; Chase 2004) to represent the entire milking period. It was assumed that dairy cows were in milk for 11 months and dry for 2 months with a calving interval of 13 months. Therefore, an 11/13 coefficient was applied to herd feed-to-milk $\mathrm{N}$ efficiency to include the unproductive period of dry cows. A dairy cattle was assumed to have a similar feed-to-cattle $\mathrm{N}$ efficiency as beef cattle and was therefore included in the calculation of the feed-to-cattle $\mathrm{N}$ efficiency factor. Similarly, dairy calves were also included in the feed-tocattle $\mathrm{N}$ efficiency. This resulted in a potential feed-tomilk $\mathrm{N}$ efficiency of $30 \%$ when including the dry period (N flow: feed to milk, Table 2), close to the values found in other studies (Table 2).

Feed-to-cattle $\mathrm{N}$ efficiency was calculated for a 16month-old animal by calculating a weighted mean of feed-to-beef efficiencies at three stages of its life According to Micol et al. (2003), the N efficiency of a newborn $50-\mathrm{kg}$ calf was $8.4 \%$ due to its mother's gestation and maintenance. The $\mathrm{N}$ efficiency of a 200$\mathrm{kg}$ calf before weaning was $16.7 \%$, including its mother's milk production efficiency and maintenance cost. The $\mathrm{N}$ efficiency of a weaned animal up to its slaughter at $550 \mathrm{~kg}$ live weight was $20 \%$ (Biagini and Lazzaroni 2013). This resulted in a potential feedto-cattle $\mathrm{N}$ efficiency of $17 \%$ from birth to slaughter, including gestation and milk production for the calf $(\mathrm{N}$ flow: feed to cattle, Table 2).

The feed-to-pig $\mathrm{N}$ efficiency ( $41 \%$; $\mathrm{N}$ flow: feed to pig, Table 2) was taken from Cederberg and Flysjö (2004) and included sows and piglets (Table 2). This potential efficiency was not directly observed in an experiment but was calculated by the authors based on the best available techniques for improved feed-to-pig $\mathrm{N}$ efficiency.

The feed-to-egg N efficiency was based on Singh et al. (2009) for laying hens 20-60 weeks old, with a mean feed conversion ratio of 1.81 and a crude protein content of $16.5 \%$ in feed. Feed-to-hen meat $\mathrm{N}$ efficiency was not included in egg production. It was assumed to be similar to feed-to-poultry $\mathrm{N}$ efficiency. This resulted in a potential feed-to-egg $\mathrm{N}$ efficiency of $40 \%$ ( $\mathrm{N}$ flow: feed to egg, Table 2).

Feed-to-poultry $\mathrm{N}$ efficiency was calculated from Ebling et al. (2013) for a broiler reaching $3.65 \mathrm{~kg}$ live weight in 47 days with a feed conversion ratio of 1.67 and a crude protein content of $20.8 \%$ in feed. Egg production was included in the feed-to-poultry $\mathrm{N}$ efficiency. This led to a potential feed-to-poultry $\mathrm{N}$ efficiency of $57 \%$ (N flow: feed to poultry, Table 2).

\subsubsection{Calculation of potential $N$ efficiency}

Figure 2 presents the data from Table 2 in a graphical manner, which can be more convenient to understand the calculation methods for potential efficiency at the farming system scale. Calculating potential $\mathrm{N}$ efficiency begins with potential crop $\mathrm{N}$ efficiency. Based on potential $\mathrm{N}$ efficiency values (Table 2) and assuming a full recycling of harvest residues, the external inputs necessary to produce net crop output are calculated as:

external input $=$ total input - harvest losses

with

total input $=\frac{\text { net crop output }}{\text { harvest efficiency } \times \text { uptake efficiency } \times \text { input efficiency }}$

and

harvest losses $=\frac{\text { net crop output }}{\text { harvest efficiency }} \times(1$-harvest efficiency $)$.

Potential N efficiency for net crop production is therefore:

potential efficiency $=\frac{\text { net crop output }}{\text { external input }}$.

Solving these equations for one unit of net crop output led to an external input of 1.11 and thus a potential crop efficiency of $90 \%$. 
The animal $\mathrm{N}$ efficiency perimeter is larger because animals consume crops and produce animal products as well as manure (Fig. 2). The calculation of external input is expressed as:

external input $=$ total input-harvest losses-recycled manure

with

total input $=\frac{\text { net animal output }}{\text { feed efficiency } \times \text { feed production efficiency } \times \text { harvest efficiency } \times \text { uptake efficiency } \times \text { input efficiency }}$

and

harvest losses $=\frac{\text { net animal output }}{\text { feed efficiency } \times \text { feed production efficiency } \times \text { harvest efficiency }} \times(1-\mathrm{h}$ arvest efficiency)

and

recycled manure $=\left(\frac{\text { net animal output }}{\text { feed efficiency }}-\right.$ net animal output $) \times$ manure efficiency

Potential $\mathrm{N}$ efficiency for net animal production can then be calculated as:

potential efficiency $=\frac{\text { net animal output }}{\text { external input }}$.

This leads to potential $\mathrm{N}$ efficiencies of $26 \%$ for cattle, $48 \%$ for eggs, $39 \%$ for milk, $49 \%$ for pig, and $59 \%$ for poultry, including all steps from inputs to outputs as well as full recycling of manure and harvest losses.

For a farming system producing more than one output, potential $\mathrm{N}$ efficiency is calculated as the ratio of the sum of its net outputs to the sum of their minimal external inputs. Minimal external input for a given output is calculated as the ratio of net output to its potential efficiency. For example, a farm in the sample produced $30 \mathrm{~kg} \mathrm{~N}^{-1}$ net cattle output and $20 \mathrm{~kg} \mathrm{~N} \mathrm{ha}^{-1}$ net crop output; its potential efficiency is therefore:

potential efficiency $=\frac{30+20}{\frac{30}{0.26}+\frac{20}{0.90}}=36 \%$.

Relative $\mathrm{N}$ efficiency can then be calculated as the ratio between observed system $\mathrm{N}$ efficiency and potential $\mathrm{N}$ efficiency:

relative $N$ efficiency $=$ system $N$ efficiency/potential efficiency.

Using the previous example, a farm that produces $30 \mathrm{~kg} \mathrm{~N} \mathrm{ha}{ }^{-1}$ net cattle output and $20 \mathrm{~kg} \mathrm{~N}^{-1}$ net crop output has a potential efficiency of $36 \%$. If its actual system $\mathrm{N}$ efficiency is $20 \%$, its relative $\mathrm{N}$ efficiency is expressed as:

relative $N$ efficiency $=0.20 / 0.36=55 \%$.

Given its net production and observed efficiency, it attained a relative $\mathrm{N}$ efficiency of $55 \%$ of its potential efficiency, which indicates room for improvement.

Regardless of the shares of animal and crop $\mathrm{N}$ in total $\mathrm{N}$ output, the closer relative $\mathrm{N}$ efficiency is to $100 \%$, the closer the farming system is to its potential efficiency. The calculation of relative $\mathrm{N}$ efficiency for each of the 557 farms based on potential $\mathrm{N}$ efficiencies and each farm's net outputs allows comparisons of relative efficiency among farms with different types of production.

2.3 Validation of relative $\mathrm{N}$ efficiency by the relative residual input approach

As a novel indicator, relative $\mathrm{N}$ efficiency had to be validated, especially concerning the choice of potential efficiency values (Table 2). The analysis of residues from a multiple linear regression between $\mathrm{N}$ inputs and outputs was proposed as another method to estimate farming systems efficiency without using potential efficiency values. Our large sample made it possible to calculate a multiple linear regression predicting net $\mathrm{N}$ input from all net $\mathrm{N}$ outputs. The residue was calculated as the difference between predicted net input (from 
regression based on net outputs) and measured net input (from surveys):

residual net input $=$ predicted net input-measured net input

Residual net input was then expressed as a fraction of predicted net $\mathrm{N}$ input:

relative residual input $=$ residual net input/predicted net input

Relative residual input could be interpreted as an $\mathrm{N}$ efficiency indicator: a negative relative residual input indicated a farming system that needed more input than what the multiple linear regression estimated for a given net output, and thus a farming system less efficient than the "average farm" with the same production. Conversely, a positive relative residual input indicated a farming system that used less net input than the multiple linear regression estimated for a given production and that was therefore more efficient.

Relative $\mathrm{N}$ efficiency and relative residual input were calculated for the 557 farms. We compared the ranking of farming systems in order to determine whether both indicators gave similar results.

\subsection{Statistical analysis}

All statistical tests were performed with the R software ( $\mathrm{R}$ Core Team 2014). Linear models of net $\mathrm{N}$ input from all combinations of net $\mathrm{N}$ outputs were calculated from the 557-farm sample. The best model was selected with the Bayesian Information Criterion (BIC).

Spearman's rank correlation coefficients and associated $p$ values were calculated for $\mathrm{N}$ efficiency indicators. Analyses of variance were performed to compare the mean of system $\mathrm{N}$ efficiency and relative $\mathrm{N}$ efficiency indicators for each production category. The means of system $\mathrm{N}$ efficiency and relative $\mathrm{N}$ efficiency were then compared for each pair of categories to determine significant differences. The Games-Howell test was chosen for pairwise comparisons of groups with unequal sizes and unequal variances.

Sensitivity analysis was performed to asses the reliability of the relative $\mathrm{N}$ efficiency indicator with uncertain potential efficiency values. Potential efficiencies (Table 2) were attributed normal distributions with a range of $\pm 20 \%$ from their baseline values. A set of 1000 random combinations of potential efficiencies was generated. Spearman's rank correlations were then calculated for the nine farming systems (Table 1).

\section{Results and discussion}

3.1 Relative residual input approach for validating relative $\mathrm{N}$ efficiency

The linear model of net $\mathrm{N}$ input based on all $\mathrm{N}$ net outputs (net out) was:

$$
\begin{aligned}
\text { preticted net input }= & 69.37+6.22^{\prime} \text { net out cattle }+1.42^{\prime} \text { net out crop } \\
& +3.74^{\prime} \text { net out egg }+4.46^{\prime} \text { net out milk } \\
& +3.62^{\prime} \text { net out pig }+2.53^{\prime} \text { net out poultry }
\end{aligned}
$$

The standard errors of estimates were, respectively, 6.99 for the intercept, 0.34 for cattle, 0.16 for crops, 0.30 for eggs, 0.12 for milk, 0.05 for pig, and 0.16 for poultry net outputs. All variables of the linear model were significant $(p<0.001)$. According to the BIC test, all variables were needed to obtain the best linear model. The adjusted $R^{2}$ of the full model was 0.92 and was significant $(\mathrm{F}(6550)=1054, p<0.001$; $\mathrm{RSE}=$ 100). It was therefore considered a good estimator of net $\mathrm{N}$ input. The high and significant adjusted $R^{2}$ of the model illustrated that net inputs and net outputs were strongly linked. Moreover, from the small standard errors of estimates, we concluded that variability was moderate for each output type. The relatively high intercept value represented $\mathrm{N}$ inputs weakly linked to production, such as atmospheric deposition, soil $\mathrm{N}$ fixation, emissions from fuel consumption, and soil $\mathrm{N}$ change.

Spearman's rank correlation between relative $\mathrm{N}$ efficiency and relative residual input was significant on the full dataset $(\mathrm{rho}=$ $-0.81, p<0.001$ ). Rank correlation between relative $\mathrm{N}$ efficiency and relative residual input for each of the nine farm categories ranged from -0.71 for the beef cattle category to -0.94 for the pig category. The correlation was significant $(p<0.001)$ for all categories. The strong correlation between these two indicators confirmed that the potential efficiency values (Table 2) used to calculate relative $\mathrm{N}$ efficiency were coherent with sample data.

In the multiple linear regression, the inverse of each estimate corresponded to the mean observed $\mathrm{N}$ efficiency for each output type. Therefore, observed efficiency was $16 \%$ for cattle output, $70 \%$ for crop output, $27 \%$ for egg output, $22 \%$ for milk output, $28 \%$ for pig output, and $40 \%$ for poultry output. The ranking of output types was the same in our sample as the values of potential efficiency found in the literature (Table 2), corroborating our choices.

\subsection{Main utility of relative $\mathrm{N}$ efficiency}

Analysis of variance showed a significant effect of production category on system $\mathrm{N}$ efficiency $(\mathrm{F}(8,548)=38.570, p<0.001)$. Pairwise comparison of means revealed five overlapping groups of comparable system $\mathrm{N}$ efficiency. Conversely, analysis of variance between production category and relative $\mathrm{N}$ efficiency was 
System N

efficiency $(\%)$

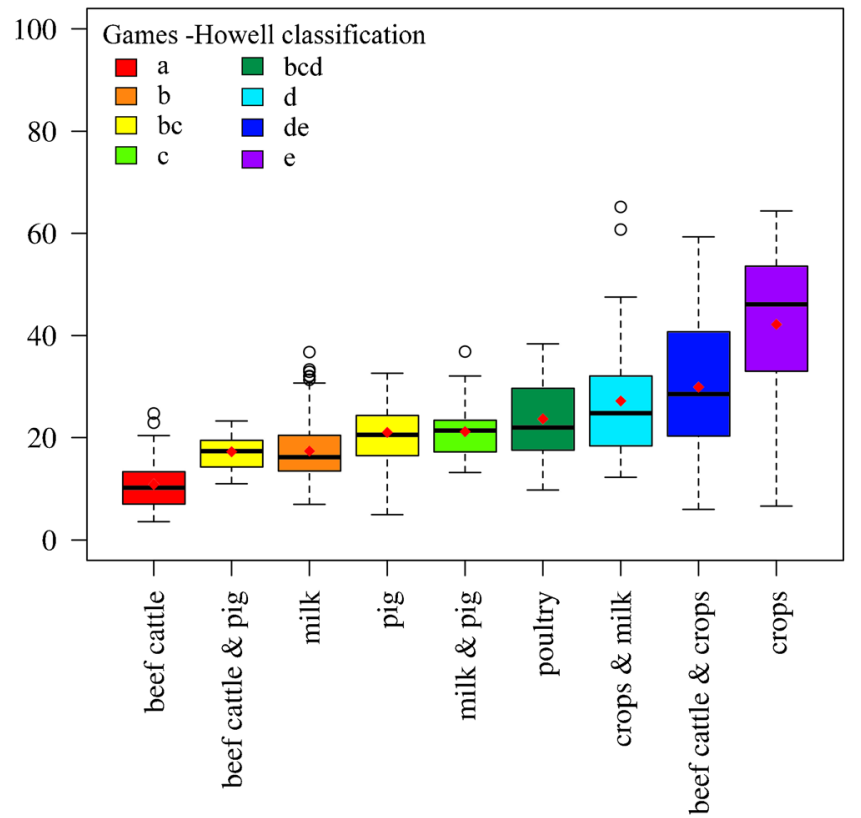

Relative $\mathbf{N}$

efficiency $(\%)$

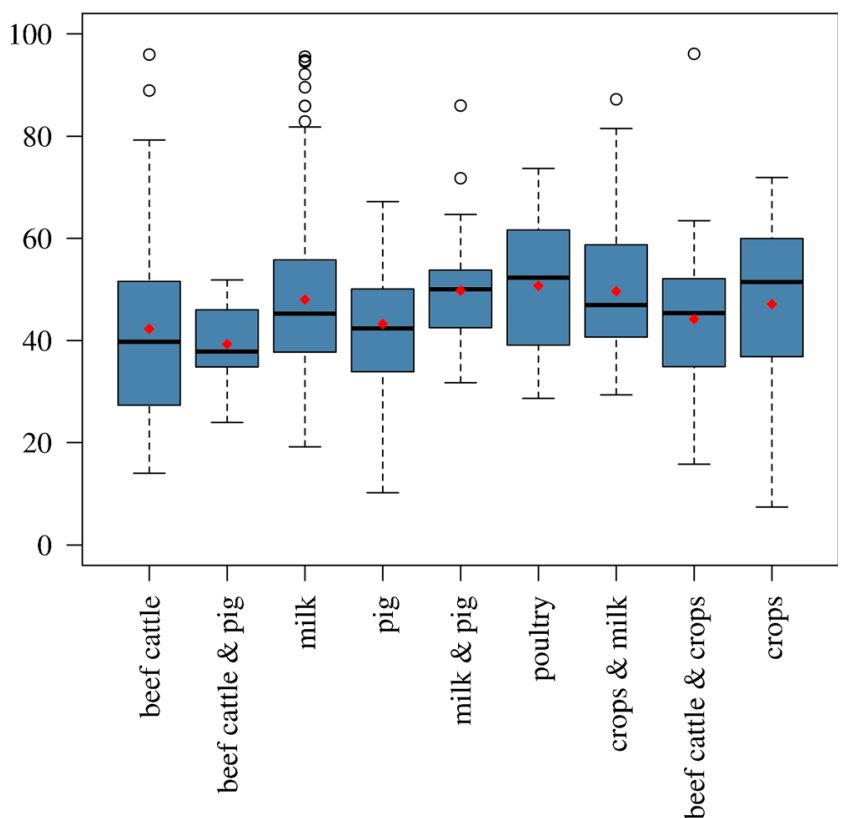

Fig. 3 Comparison of system $\mathrm{N}$ efficiency and relative $\mathrm{N}$ efficiency by production category. Diamonds represent the mean of each category. Twelve outliers with relative $\mathrm{N}$ efficiency $>100 \%$ are not shown

not significant $(\mathrm{F}(8,548)=1.517, p=0.148>0.05)$. We thus conclude that relative $\mathrm{N}$ efficiency can be used to compare the relative efficiency of farming systems with different types of production.

All production categories were able to reach a high relative $\mathrm{N}$ efficiency. The mean relative $\mathrm{N}$ efficiencies of all categories were similar, ranging from $39 \%$ for beef cattle and pig to $54 \%$ for poultry. This result showed that in our sample, relative $\mathrm{N}$ management was no better on crop farms than on beef cattle farms. Relative $\mathrm{N}$ efficiency had high variability within each category (boxplot whiskers, Fig. 3), especially beef cattle, milk and crop productions. This was due to the large diversity in production methods for these categories in our sample including conventional, organic, and "autonomous" farms in different regions.

Plotting system $\mathrm{N}$ efficiency versus relative $\mathrm{N}$ efficiency illustrates major differences in potential between production types (Fig. 4). For instance, four different types of specialized farms in the sample (crop, pig, dairy, and beef cattle) had the same system $\mathrm{N}$ efficiency (14\%) but different relative $\mathrm{N}$ efficiencies (16, 28, 38, and $56 \%$, respectively) based on what they produced. The farms with the highest system $\mathrm{N}$ efficiencies produced crops (Fig. 4). Conversely, the farms with the highest relative $\mathrm{N}$ efficiencies occurred in all production types, not only crop farms, but also beef cattle or dairy farms, which have lower inherent $\mathrm{N}$ efficiencies.

This indicator is also pertinent for comparing farming systems that produce the same or similar products in different percentages. For example, two farms in the crop and milk category produced net milk, meat and crop outputs and had a system $\mathrm{N}$ efficiency of $29 \%$. With this indicator alone, one would have concluded that they had the same $\mathrm{N}$ efficiency.
However, the two farms produced different percentages of total $\mathrm{N}$ output in milk, cattle meat, and crops $(46,38$, and $17 \%$ vs. 19,9 , and $72 \%$, respectively), leading to greatly different relative $\mathrm{N}$ efficiencies ( 80 and $44 \%$, respectively).

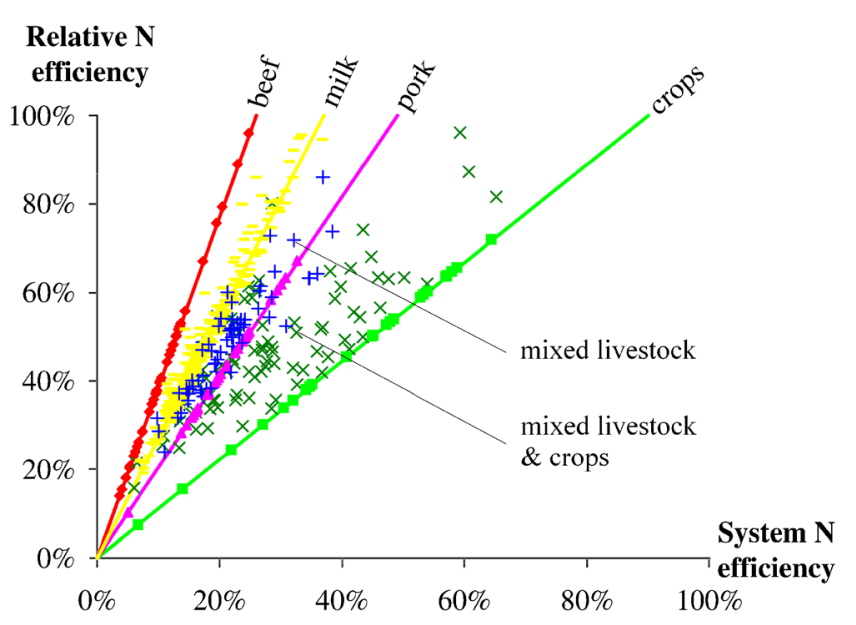

Fig. 4 Comparison of system $\mathrm{N}$ efficiency and relative $\mathrm{N}$ efficiency for the 557-farm sample. Farming systems with crops have greater system $\mathrm{N}$ efficiency than livestock farming systems but not necessarily greater relative $\mathrm{N}$ efficiency. Diagonal lines represent the relationship between system $\mathrm{N}$ efficiency and relative $\mathrm{N}$ efficiency for specialized farming systems with $100 \%$ relative efficiency equal to potential efficiency value for given output. Specialized dairy systems show some variation around the diagonal due to the variable share of milk and meat outputs. Mixed livestock is the sum of beef cattle and pig, milk and pig and poultry; mixed livestock and crops is the sum of beef cattle and crops and crops and milk. Twelve outliers with relative $\mathrm{N}$ efficiency $>100 \%$ are not shown 
The mixed livestock and crop category (gathering beef and crops and crops and milk categories, Fig. 4) illustrates the great diversity of crop and livestock proportions in mixed systems, from almost specialized beef cattle to almost specialized crops. Some farms of this category have both a higher system $\mathrm{N}$ efficiency and a lower relative $\mathrm{N}$ efficiency than other farms with less crops. In this situation, the use of relative $\mathrm{N}$ efficiency is particularly interesting to compare $\mathrm{N}$ management efficiency between farms with different outputs.

\subsection{Relative $\mathrm{N}$ efficiency as a reliable diagnosis tool}

Relative $\mathrm{N}$ efficiency helps to better estimate any farming system's "room for improvement". Within each category, some farms lie below $30 \%$ and others above $50 \%$ of their potential efficiency, which illustrates a large gap between actual and potential efficiency for some farms. Therefore, relative $\mathrm{N}$ efficiency can be a useful diagnostic tool to quickly assess which production could be improved on a given farm (but not how to improve it).

In order to test the sensitivity of relative $\mathrm{N}$ efficiency to chosen potential efficiency values, we checked the effect of $\pm 20 \%$ changes of all potential efficiencies simultaneously on the relative $\mathrm{N}$ efficiency of the nine average farming systems described in Table 1. Rank correlations were then calculated to determine whether the variation of potential efficiency values had an impact on the ranking of these nine average farming systems. Observed rank correlations were greater than 0.95 between relative $\mathrm{N}$ efficiency of all animal farming systems except beef and crops, and greater than 0.90 between all farming systems except crops. Rank correlations between crops and other systems ranged from 0.65 to 0.87 . Therefore, $\mathrm{a} \pm 20 \%$ change in potential efficiency did not strongly affect the ranking of farming systems and thus the interest of relative $\mathrm{N}$ efficiency for comparing them.

Potential efficiency was defined by references from literature for each output type. Another method could be to use the calculated system $\mathrm{N}$ efficiency from the most efficient specialized farms of the sample. This might prove interesting when studying productions whose potential efficiency references are lacking (e.g., flowers, vine, etc.). It would also be adapted for the study of farming systems in contexts where potential efficiency cannot be attained due to soil, climate, or technical limitations. However, it is less generic than the approach we proposed, as potential efficiency would be defined from each sample, which would make comparisons between studies impractical. Moreover, it would require a large number of specialized farms for correct potential efficiency definition, and would thus not be pertinent for a small sample or a single farm. Finally, as the estimation of some $\mathrm{N}$ inputs (soil $\mathrm{N}$ change, biological $\mathrm{N}$ fixation) is uncertain, the most efficient farming systems of a sample could also be underestimating their inputs, which could skew the potential efficiency value.

Since the references we used were comforted by comparing relative $\mathrm{N}$ efficiency to relative residual input, and since $\pm 20 \%$ uncertainty did not have profound effects on relative $\mathrm{N}$ efficiency results, this indicator seems reliable.

Unlike a statistical approach, it can be calculated with a small dataset or even for one farm, making it a convenient tool for farm diagnosis. Calculating $\mathrm{N}$ efficiency for each net output is simple and allows comparisons between breeds or production methods that produce different proportions of coproducts such as milk and meat.

\subsection{Limits of relative $\mathrm{N}$ efficiency}

\subsubsection{Limits due to estimation of $N$ flows}

Twelve outliers ( $2.2 \%$ of the sample) had relative $\mathrm{N}$ efficiencies greater than $100 \%$. Due to the high values used for potential N efficiencies, it is unlikely that these incorrect results come from efficient farming systems exceeding the indicator's limits. It is more probable that some $\mathrm{N}$ inputs were underestimated. This hypothesis is strengthened by the fact that all outlier farms had net inputs lower than the mean of $343 \mathrm{~kg} \mathrm{~N} \mathrm{ha}^{-1}$, and nine of them were in the lowest $10 \%$ of farms (below $95 \mathrm{~kg} \mathrm{~N} \mathrm{ha}^{-1}$ ). Eight of them had over two thirds of permanent pasture in their agricultural area, while two had over one third of temporary grasslands with clover in their AA. A small underestimation in symbiotic fixation or a small overestimation of soil $\mathrm{N}$ storage in these farms with low inputs could thus have a large impact on relative $\mathrm{N}$ efficiency.

In our sample, most flows derived from purchases and sales of products. For most inputs, this method had low uncertainty (Oenema et al. 2003). For soil $\mathrm{N}$ changes and biological fixation by legumes, however, rough calculation rules were used due to the lack of data for the former and to the large uncertainty in the latter. Biological $\mathrm{N}$ fixation was already recognized as a large source of uncertainty in farm $\mathrm{N}$ budgets (Nimmo et al. 2013; Payraudeau et al. 2007), while soil N change is usually ignored due to its complexity. These variables were found to be highly influential on system $\mathrm{N}$ efficiency in another study (Godinot et al. 2014) and are likely to explain the presence of 12 outliers with RNE greater than $100 \%$ in our sample. Therefore, more work is needed to better estimate them to reduce uncertainty and avoid relative $\mathrm{N}$ efficiency aberrations.

\subsubsection{Limits due to potential $N$ efficiency values}

The highest potential $\mathrm{N}$ efficiency values found in the literature were used in this work. These do not consider production potential linked to local conditions such as soil fertility, climate, water availability, pests, and weeds; nor do they consider input availability, crop and animal breed choices or farm equipment. Moreover, actual $\mathrm{N}$ use efficiency at the system scale is substantially lower than what can be achieved in research experiments (Goulding et al. 2008). Therefore, the potential $\mathrm{N}$ efficiencies used in this study should not be considered as realistic targets but rather as initial maximum values to calculate relative $\mathrm{N}$ efficiency. 
The same crop efficiency (soil to harvestable crop, Table 2) was used for all crops, though plants have different $\mathrm{N}$ efficiencies. For instance, cereals are more $\mathrm{N}$ efficient than root crops (Task Force on Reactive Nitrogen 2011). Since we could not find references according to crop type, it appeared more simple and robust to use a single value. This could be improved in further development of the indicator when references are available. Similarly, only the highest value of harvest efficiency $(95 \%)$ was used. It corresponds to silage maize whose above-ground biomass is almost entirely harvested, while most crops leave large amounts of residues in fields. However, the assumption of recycling of crop residues when calculating relative $\mathrm{N}$ efficiency moderates this issue. For instance, harvesting $95 \%$ of a crop and recycling $5 \%$ leads to a potential crop efficiency of $90 \%$ (see section 2.2.2), while harvesting $50 \%$ and recycling $50 \%$ (common for some vegetables) leads to a potential crop efficiency of $82 \%$. Moreover, most crops relocate $\mathrm{N}$ into grains at maturity greatly increasing their $\mathrm{N}$ harvest index compared to their biomass harvest index.

Net flows of animals were calculated by subtracting animals of each species purchased from those sold. However, animal age has a major impact on $\mathrm{N}$ use efficiency: feed conversion ratio usually decreases with age, but the needs of the mother for pregnancy, maintenance, and milk production greatly reduces the efficiency of young animals. Therefore, considering all animals of the same species equal is an imperfect solution. This bias favors farming systems that buy young animals instead of breeding them. To estimate the importance of this bias to relative $\mathrm{N}$ efficiency, we compared pig farms that only breed $(n=10)$, only fatten $(n=19)$, or do both $(n=50)$. No significant difference was found for relative $\mathrm{N}$ efficiency between these groups $(\mathrm{F}(2,76)=2.297 ; p=0.107>0.05)$. The bias was therefore considered acceptable, and the indicator was not modified to address this specific point. Animal efficiency does not consider their feed and/or forage rations. It is known that feed $\mathrm{N}$ content impacts feed conversion ratio (Powell et al. 2010). For the sake of generality, a single value was chosen for the potential efficiency of all rations for a given animal product. Different animal breeds also have different feed conversion ratios, which were not considered in this simple indicator.

All farm manure was considered recycled on cropping systems. Exporting it to other farms did not modify the indicator, since it was then considered to be recycled in other farming systems and treated as a negative fertilizer input. However, best available techniques for manure storage and management are not yet widespread. Moreover, manure spreading on soils should not always be considered as manure recycling, as losses can be very important when soil $\mathrm{N}$ status does not require additional $\mathrm{N}$ input. Therefore, the assumption that $77 \%$ of manure $\mathrm{N}$ is recycled into the soil seems highly optimistic.
In spite of these limits, a $\pm 20 \%$ variation of potential efficiencies did not greatly affect the ranking of average farming systems, making relative $\mathrm{N}$ efficiency a perfectible but reliable indicator. Differences in calculation perimeters between crops and animal products, however, make uncertainty a bigger issue when comparing crop farming systems and animal farming systems. Meta-analysis of published potential NUE references would provide better estimates than the single reference values used in this study, and would allow to express the level of uncertainty of potential NUE on the results of relative $\mathrm{N}$ efficiency (Doré et al. 2011).

\section{Conclusion}

Relative $\mathrm{N}$ efficiency is a novel indicator that compares observed system $\mathrm{N}$ efficiency to a potential value that could be attained for a similar combination of farm products. It thus considers production type when calculating $\mathrm{N}$ efficiency at the farming system scale, making relative comparisons possible among different farming systems. The main utility of this indicator is to compare relative efficiencies of farms that produce products of different trophic levels, which is more useful to farmers than the correct but unhelpful observation that producing more crops and fewer animal products increases absolute $\mathrm{N}$ efficiency. It is particularly useful for comparing mixed farming systems to each other or to specialized systems. Relative $\mathrm{N}$ efficiency is therefore a valuable diagnosis tool to identify efficient $\mathrm{N}$ management in farming systems. It also provides a simple assessment of the theoretical room for improvement of a given farm. However, the simplifying hypotheses used to calculate it must be considered when comparing results. This indicator is a useful step toward the identification and development of efficient practices and systems for crop and livestock production.

Acknowledgments The authors are grateful to Michelle and Michael S. Corson for English proofreading. The authors also thank three anonymous reviewers for their constructive remarks and comments, which greatly improved the quality of this article.

\section{References}

Aarts HFM, Habekotté B, Van Keulen H (2000) Nitrogen (N) management in the "De Marke" dairy farming system. Nutr Cycl Agroecosyst 56:231-240. doi:10.1023/A:1009885419512

Andrews M, Scholefield D, Abberton MT et al (2007) Use of white clover as an alternative to nitrogen fertiliser for dairy pastures in nitrate vulnerable zones in the UK: productivity, environmental impact and economic considerations. Ann Appl Biol 151:11-23. doi:10. $1111 / j .1744-7348.2007 .00137 . x$ 
Biagini D, Lazzaroni C (2013) Nitrogen excretion in fattening beef in conventional vs. extensive and sustainable farm systems. EAAP Book Abstr. Wageningen Academic Publishers, Nantes, p 198

Castel F, Pous B (1998) Alimentation animale: la réforme de la PAC a favorisé le recours aux céréales et aux tourteaux. Agreste Cah 11-17

Cederberg C, Flysjö A (2004) Environmental assessment of future pig farming systems-quantification of three scenarios from the FOOD21 synthesis work. 54

Chase LE (2004) Estimated nitrogen excretion in 46 commercial dairy herds in New York. In: Nitrogen Manag. Dairy Farms. https://www. dairyn.cornell.edu/pages/40dairy/410utilization/416excretion. shtml. Accessed 14 Jan 2014

Core Team R (2014) R: a language and environment for statistical computing. R Foundation for Statistical Computing, Vienna

Doré T, Makowski D, Malézieux E et al (2011) Facing up to the paradigm of ecological intensification in agronomy: revisiting methods, concepts and knowledge. Eur J Agron 34:197-210. doi:10.1016/j.eja. 2011.02.006

Ebling P, Ribeiro A, Trevizan L et al (2013) Effect of different dietary concentrations of amino acids on the performance of two different broiler strains. Rev Bras Ciênc Avícola 15:339-346. doi:10.1590/ S1516-635X2013000400008

Eggleston S, Buendia L, Miwa K et al (2006) IPCC guidelines for national greenhouse gas inventories. Institute for Global Environmental Strategies, Hayama

EMEP (2014) EMEP MSC-W modelled air concentrations and depositions. http://webdab.emep.int/Unified_Model_Results/. Accessed 5 Mar 2014

Godinot O, Carof M, Vertès F, Leterme P (2014) SyNE: an improved indicator to assess nitrogen efficiency of farming systems. Agric Syst 127:41-52. doi:10.1016/j.agsy.2014.01.003

Górny AG, Banaszak Z, Ługowska B, Ratajczak D (2011) Inheritance of the efficiency of nitrogen uptake and utilization in winter wheat (Triticum aestivum L.) under diverse nutrition levels. Euphytica 177:191-206. doi:10.1007/s10681-010-0230-z

Goulding K, Jarvis S, Whitmore A (2008) Optimizing nutrient management for farm systems. Philos Trans R Soc B Biol Sci 363:667-680. doi:10.1098/rstb.2007.2177

Gourley CJP, Aarons SR, Powell JM (2012) Nitrogen use efficiency and manure management practices in contrasting dairy production systems. Agric Ecosyst Environ 147:73-81. doi:10.1016/j.agee.2011. 05.011

Halberg N, Verschuur G, Goodlass G (2005) Farm level environmental indicators; are they useful? An overview of green accounting systems for European farms. Agric Ecosyst Environ 105:195-212. doi: 10.1016/j.agee.2004.04.003

Lebacq T, Baret PV, Stilmant D (2012) Sustainability indicators for livestock farming. A review. Agron Sustain Dev 33:311-327. doi:10. 1007/s13593-012-0121-X

Micol D, Hoch T, Agabriel J (2003) Besoins protéiques et maîtrise des rejets azotés du bovin producteur de viande. Fourrages 174:231-242

Moll RH, Kamprath EJ, Jackson WA (1982) Analysis and interpretation of factors which contribute to efficiency of nitrogen utilization. Agron J 74:562-564. doi:10.2134/agronj1982. $00021962007400030037 x$

Nevens F, Verbruggen I, Reheul D, Hofman G (2006) Farm gate nitrogen surpluses and nitrogen use efficiency of specialized dairy farms in Flanders: evolution and future goals. Agric Syst 88:142-155. doi: 10.1016/j.agsy.2005.03.005

Nimmo J, Lynch DH, Owen J (2013) Quantification of nitrogen inputs from biological nitrogen fixation to whole farm nitrogen budgets of two dairy farms in Atlantic Canada. Nutr Cycl Agroecosyst 96:93105. doi:10.1007/s10705-013-9579-4

Oenema O, Kros H, de Vries W (2003) Approaches and uncertainties in nutrient budgets: implications for nutrient management and environmental policies. Eur J Agron 20:3-16. doi:10.1016/S11610301(03)00067-4

Oenema O, Witzke HP, Klimont Z et al (2009) Integrated assessment of promising measures to decrease nitrogen losses from agriculture in EU-27. Agric Ecosyst Environ 133:280-288. doi:10.1016/j.agee. 2009.04.025

Oenema J, van Ittersum M, van Keulen H (2012) Improving nitrogen management on grassland on commercial pilot dairy farms in the Netherlands. Agric Ecosyst Environ 162:116-126. doi:10.1016/j. agee.2012.08.012

Payraudeau S, van der Werf HMG, Vertes F (2007) Analysis of the uncertainty associated with the estimation of nitrogen losses from farming systems. Agric Syst 94:416-430. doi:10.1016/j.agsy.2006. 11.014

Powell JM, Gourley CJP, Rotz CA, Weaver DM (2010) Nitrogen use efficiency: a potential performance indicator and policy tool for dairy farms. Environ Sci Policy 13:217-228. doi:10.1016/j.envsci. 2010.03.007

Ramírez E, Reheul D (2009) Statistical modelling of nitrogen use efficiency of dairy farms in Flanders. Agron Sustain Dev 29:14. doi:10. 1051/agro/2008065

Rios RL, Bertechini AG, Carvalho JCC et al (2009) Effect of cage density on the performance of 25 to 84-week-old laying hens. Rev Bras Ciênc Avícola 11:257-262

Rotz CA (2004) Management to reduce nitrogen losses in animal production. J Anim Sci 82:E119-E137

Rotz CA, Corson MS, Chianese DS et al (2012) Integrated Farm System Model (IFSM): reference manual version 3.6. USDA, Washington

Schröder JJ, Aarts HFM, ten Berge HFM et al (2003) An evaluation of whole-farm nitrogen balances and related indices for efficient nitrogen use. Eur J Agron 20:33-44. doi:10.1016/S1161-0301(03) 00070-4

Simon J-C, Grignani C, Jacquet A et al (2000) Typologie des bilans d'azote de divers types d'exploitation agricole: recherche d'indicateurs de fonctionnement. Agronomie 20:21. doi:10.1051/ agro:2000118

Singh R, Cheng KM, Silversides FG (2009) Production performance and egg quality of four strains of laying hens kept in conventional cages and floor pens. Poult Sci 88:256-264. doi:10.3382/ps.2008-00237

Spiertz JHJ (2010) Nitrogen, sustainable agriculture and food security. A review. Agron Sustain Dev 30:43-55. doi:10.1051/agro:2008064

Steinshamn H, Thuen E, Bleken MA et al (2004) Utilization of nitrogen $(\mathrm{N})$ and phosphorus $(\mathrm{P})$ in an organic dairy farming system in Norway. Agric Ecosyst Environ 104:509-522. doi:10.1016/j.agee. 2004.01.022

Sutton MA, Howard CM, Erisman JW, et al. (2011) The European nitrogen assessment: sources, effects, and policy perspectives. Cambridge University Press, Cambridge (UK). doi: 10.1017/ CBO9780511976988

Task Force on Reactive Nitrogen (2011) Draft guidance document for preventing and abating ammonia emissions from agricultural sources. 109

UNIFA (2014) La fertilisation en France. http://www.unifa.fr/le-marcheen-chiffres/la-fertilisation-en-france.html. Accessed 10 Mar 2014

Van der Hoek KW (1998) Nitrogen efficiency in global animal production. Environ Pollut 102:127-132. doi:10.1016/S0269-7491(98) 80025-0

Vleeshouwers LM, Verhagen A (2002) Carbon emission and sequestration by agricultural land use: a model study for Europe. Glob Chang Biol 8:519-530. doi:10.1046/j.1365-2486.2002.00485.x

Zavattaro L, Monaco S, Sacco D, Grignani C (2012) Options to reduce $\mathrm{N}$ loss from maize in intensive cropping systems in Northern Italy. Agric Ecosyst Environ 147:24-35. doi:10. 1016/j.agee.2011.05.020 